\title{
Influence of concrete admixture on the bond strength of reinforced concrete submitted to high temperature
}

\section{Estudo do comportamento da aderência aço-concreto sob o efeito de altas temperaturas}

V. A. JERÔNIMO vanessa-jeronimo@hotmail.com https://orcid.org/0000-0001-8707-5889

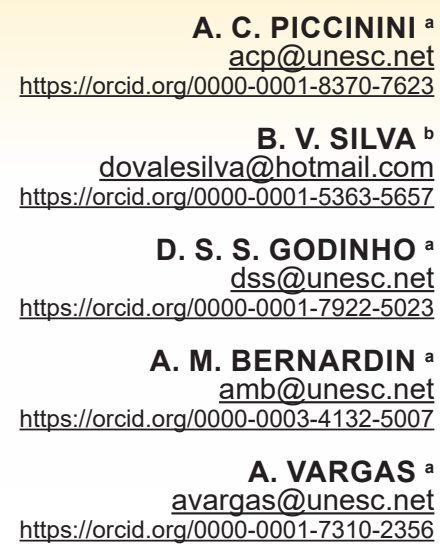

\begin{abstract}
High temperatures can affect the macro and micro structural properties of reinforced concrete. This work aimed to analyze the bond strength behavior after high temperature exposure of two classes of concrete, the conventional $30 \mathrm{MPa}$ and the high compressive strength $65 \mathrm{MPa}$ concrete. The pullout test proposed by RILEM CEB / FIP RC6 (1983) was used for the evaluation of the compressive strength and modulus of elasticity. The influence of temperature on the physical-mechanical properties of concrete samples under a simulated fire situation was also studied for the evaluation of the resistant capacity in a post-fire situation. In addition to the analysis at 28 days, samples of the $30 \mathrm{MPa}$ (group I) and $65 \mathrm{MPa}$ (group II) classes were also investigated at 90 days exposed to room $\left(23^{\circ} \mathrm{C}\right), 400^{\circ} \mathrm{C}$ and $800^{\circ} \mathrm{C}$ temperatures. The bond strength curve was similar to that of compressive strength, where, at $400{ }^{\circ} \mathrm{C}$, there was no statistical difference regarding room temperature and, at $800{ }^{\circ} \mathrm{C}$, there was significant loss of strength in all cases. At 90 days age there was a loss of bond strength of 51 and $40 \%$ for groups I and II, respectively. At $800^{\circ} \mathrm{C}$ the reductions were above $50 \%$ in compressive strength and above $80 \%$ in the modulus of elasticity, for both groups. These results show the structural impairment under high temperature. Comparing the test 28 and 90 days ages, there was no significant influence of age on the bond and compressive strength of the concretes.
\end{abstract}

Keywords: steel-concrete bond, reinforced concrete, Pullout test, high temperature.

\section{Resumo}

O concreto armado é um material compósito formado pela interação entre o concreto e o aço e deve suas boas características à aderência entre eles, onde o concreto absorve os esforços de compressão e o aço os de tração, majoritariamente. Este trabalho tem por objetivo analisar o comportamento da tensão de aderência de duas classes de concreto após a exposição a diferentes níveis de temperatura. Utilizou-se o ensaio de arrancamento direto (Pull out test) proposto pela RILEM CEB/FIP RC6:1983 e também avaliou-se o comportamento da resistência à compressão e do módulo de elasticidade. Foram ensaiados, aos 28 e aos 90 dias de idade, corpos de prova em concreto de classes 30 MPa e 65 MPa, expostos às temperaturas ambiente $\left(23^{\circ} \mathrm{C}\right), 400^{\circ} \mathrm{C}$ e $800^{\circ} \mathrm{C}$. A curva do comportamento da aderência foi semelhante à de compressão, em que, aos $400^{\circ} \mathrm{C}$, estatisticamente, não houve variação significativa em relação à temperatura ambiente e, aos $800^{\circ} \mathrm{C}$, perda expressiva de resistência em todos os casos, chegando a $57,09 \%$ de redução na resistência à compressão e 40,05\% na resistência de aderência.

Palavras-chave: aderência aço-concreto, concreto armado, Pull Out Test, altas temperaturas. 


\section{Introduction}

The combined use of steel and concrete for structural purposes increases the tensile strength, therefore increasing the load capacity. The bond between steel and concrete is extremely important in crack control. The Brazilian standard ABNT [1] refers to reinforced concrete elements as 'those in which their structural behavior is related to the bond between concrete and reinforcement, and do not have initial reinforcement elongation before the bond.'

Tavares et al [2] express that the bond is the factor that enables the reinforcement anchorage in concrete and helps to prevent the slide of these reinforcements in the segments between the cracks, reducing their effects. Araújo [3] states that because concrete shows low tensile strength, the component cracks in the tensile zone of the structural element, therefore, the tensile stresses are absorbed by the reinforcement, preventing the immediate collapse of the structures.

A structural element with a larger number of cracks but with smaller individual opening allows better protection of the reinforcement and the greater the bond, the greater the probability of obtaining this result. [4]

Some researchers, including Araújo [3], state that the bond stress varies throughout the component, however, for design purposes; it is considered an average value. Castro [4] asserts that knowledge on bond behavior is essential for the correct sizing of anchorages and joints, calculation of displacements considering the contribution of the tensioned concrete, control of cracks and, therefore, minimum reinforcement.

According to Araújo [3] and Negrão and Pimentel [5], several factors influence the behavior of steel-concrete bond, such as: the type of bar rib configuration, the diameter of the bar and the state of its surface, the disposition at the time of casting the concrete, the water-cement ratio, the mechanical strength of the concrete, density, the age of rupture, among others.

In lower strength concretes, compressive strength is an important factor, since the pullout of the steel bar will be due to the crushing of the concrete part in front of the rib. The compressive strength can withstand the concentrated diagonal stresses generated on the steel ribs. Caetano [6] states that with the increase of concrete strength, the bond is favored; however, confinement techniques should be employed to control their tendency to break in a fragile way, as in premature splitting.

Splittings, common in high strength concrete, occur when the circumferential tensile stresses reach or exceed the concrete tensile strength. Bond on the steel-concrete interface can occur by three mechanisms: surface adhesion, friction and a dominant portion of mechanical adhesion. However, as mentioned by Oliveira and Jacintho [7], this division is solely didactic, and it is not possible to determine each component separately, due to the complexity of the phenomena involved.

When a fire strikes a building, the building can suffer considerable structural damage. Moreover, in the case of concrete, both cement and aggregates are made of elements that to a lesser or greater degree change or decompose on exposure to heat. In these situations, the reinforced concrete structure is reduced in capacity, however, for safety reasons, it must have a minimum resistance so that the site can be evacuated and the flames extinguished [8].
Under high temperatures, there are fewer researches on the behavior of the bond between steel and concrete. Therefore, few studies report the mechanical properties of concrete under fire. The bond behavior at high temperatures has been analyzed with pullout tests.

As concrete exposed to high temperature deteriorates, the friction grip mechanism is weakened and consequently the peel strength of the steel bar decreases. Since tensile strength and compressive strength are very important parameters in the analysis of bond behavior and since friction is influenced by tensile strength, with decreasing strength, that mechanism is reduced. The mechanical grip is due to the protrusions that ribbed reinforcements have. Adhesive forces are associated with concentrated compressive forces that appear perpendicular to the rib faces when the bar is pulled and tends to slide.

Ergün et al [9] comment that it is very difficult to quantify the relationship between the increase and decrease of temperature in the bond stress, as it depends on several parameters. The authors report that the studies about the bond between steel and concrete at high temperatures by Morely and Royles [10], Haddad and Shannis [11], Haddad et al. [12] and Bingol and Gul [13] report that there was a considerable loss of bond strength when the temperature increased. The results of these studies showed that the bond strength was changed between 30 and $70 \%$ according to the parameters examined, such as concrete and steel properties, diameter and heating and cooling regime, etc., when subjected to $500^{\circ} \mathrm{C}$ for 90 days.

According to Silva [14] and Lima [15], at high temperature, the concrete undergoes chemical and physical changes in which dehydration of the cement paste and volumetric variations in the aggregates occur, causing cracking. Leonhardt and Mönnig [16] state that bond stresses can prevent spalling, preventing the loss of the covering. Fletcher et al [17] point out that some of these changes are reversible after cooling, but others are not and can significantly weaken the concrete structure after a fire. If the temperature reaches $400{ }^{\circ} \mathrm{C}$ the calcium hydroxide in the cement will begin to dehydrate, generating more water vapor and also bringing a significant reduction in material strength. Quartz-based aggregates increase in volume at about $575^{\circ} \mathrm{C}$ due to a transformation of the material and at $800^{\circ} \mathrm{C}$ they are decomposed.

Studying the effects of temperature on different concrete groups, Poloju et al [18] showed that the loss on strength is greater with temperature increase in the groups with higher compressive strength. In the tests at $400{ }^{\circ} \mathrm{C}$, the class $20 \mathrm{MPa}$ concrete had $12 \%$ loss, the class $40 \mathrm{MPa} 26.9 \%$ loss and the class $60 \mathrm{MPa}$ concrete a $30.6 \%$ loss in compressive strength. Above $600^{\circ} \mathrm{C}$ this difference was less significant. In situations where variations in temperature occur, such as fires, steel heats faster than concrete due to its higher thermal conductivity, so it undergoes greater expansion.

Caetano [6] in his research observed that exposure to high temperatures considerably affects the bond strength, the effect being influential from $350^{\circ} \mathrm{C}$ and increasing after $400{ }^{\circ} \mathrm{C}$. For high strength concretes, Caetano [6] shows that from 740 to $470{ }^{\circ} \mathrm{C}$ the temperature threshold causes the reduction in bond stress of 50 $\%$, when the compressive strength was increased from 15 to 80 $\mathrm{MPa}$. The bond of the $80 \mathrm{MPa}$ concrete at $470{ }^{\circ} \mathrm{C}$ is still almost 3 times higher than that of $15 \mathrm{MPa}$ concrete at $740^{\circ} \mathrm{C}$. When the 
temperature exceeded $835^{\circ} \mathrm{C}$, the bond stress of all specimens tended to be the same.

Ergün et al [9] studying the compressive strength at $100{ }^{\circ} \mathrm{C}$ found an average increase of $1 \%$. At $200{ }^{\circ} \mathrm{C}$ an average reduction of $6 \%$. At temperatures between 400 and $600{ }^{\circ} \mathrm{C}$ a reduction of 29 to $40 \%$ and at $800{ }^{\circ} \mathrm{C}$ a large loss of $73 \%$ on average was observed. Regarding the bond stress, Ergün et al [9] found reductions of $21,27,60$ and $76 \%$ at $200,400,600$ and $800{ }^{\circ} \mathrm{C}$, respectively, at 90 days.

El-Fitiany and Youssef [19] analyzed concrete sections exposed to fire and commented that, as new codes move toward the design for fire-based situations, new tools are needed to assess the performance of heated sections under fire. According Khouri [20], in the design of fire-resistant materials the heat transfer in an element must be kept within acceptable limits through the overall section and the reinforcement must be covered with concrete in order to keep the steel temperature below critical values for the required period to reach fire resistance. Caetano [6] states that the conditions of a structure after an accident must be checked to determine the need and possibility of recovery of the structure, as well as its total or partial demolition. One of the requirements for a structural element to be safe is the existence of a minimum bond among the constituent elements.

The ABNT Brazilian standard [21] classifies concretes in resistance groups I, ordinary concretes, and II, high performance concretes (HPC), that is, showing better performance than the ordinary concretes belonging to group I, whose limit is the concrete with $50 \mathrm{MPa}$ strength. According Castro [4], the HPC concretes, besides greater resistance than ordinary concretes, show durability and workability.

In this context, further studies on the bond of steel and concrete after exposure to high temperature are needed. The present work was based on the studies of Caetano [6] and Scotton [8]. The first one studied bond in $\mathrm{C} 65$ class concretes and the second one in C30 class concretes, with the same admixtures and materials similar to those used in this research; both studies performed the tests at 28 days at room temperature in comparison with high temperature.

Therefore, the present work aims to determine the effect of temperature $\left(23,400\right.$ and $\left.800{ }^{\circ} \mathrm{C}\right)$ on the bond strength of $\mathrm{C} 30$ and C65 class concretes with the ribbed steel reinforcement after exposure. In addition to 28 days of age, tests were performed at 90 days to verify if the structural elements have reduced their adhesion resistance due to the time required for stabilization of the internal reactions of concrete in a way that could compromise the structure. The pullout test method was used to determine the compressive strength and bond stress of both classes of concrete under rising temperature $\left(23,400\right.$ and $\left.800^{\circ} \mathrm{C}\right)$ over time (28 and 90 days of age). The characteristic bond stress was compared to the effective bond stress.

\section{Materials and methods}

The tests were performed at the Building Materials Laboratory, Structural Laboratory and Mechanical Testing Laboratory, located at i-parque (Scientific and Technological Park of the Universidade do Extremo Sul de Santa Catarina) at Criciúma (SC).

The concretes showed average compressive strength at 28 days of $30 \mathrm{MPa}$ for group I and $65 \mathrm{MPa}$ for group II according to ABNT [21]. The admixtures were defined based on the works of Caetano [6] and Scotton [8] using similar materials (Table 1). CP IV cement (Cimentos Votorantim) was used for the manufacture of concrete samples. The fine aggregate had a fineness modulus of 2.37, maximum characteristic size of $2.4 \mathrm{~mm}$ and an apparent specific mass of $2.36 \mathrm{~g} / \mathrm{cm}^{3}$. The coarse aggregate, of granitic origin, showed fineness modulus of 6.65 , maximum characteristic size of $19 \mathrm{~mm}$ and apparent specific mass of $3.00 \mathrm{~g} / \mathrm{cm}^{3}$. Both aggregates were in accordance with the ABNT [22] requirements. Tap water and superplasticizer (Grace Tec-flow 7000, 1.075 $1.115 \mathrm{~g} / \mathrm{cm}^{3}$ density) were used. Ribbed steel (Gerdau CA-50) with a diameter of $12.5 \mathrm{~mm}$ and characteristic yield strength of $500 \mathrm{MPa}$ was used as reinforcement.

The concrete samples were prepared with the aid of a 400 -liter concrete mixer, therefore each concrete needed to be divided into three parts due to the large volume required. Each group was shaped in one day. The ABNT cone trunk abatement test [23] was performed, resulting in 11 and $22.8 \mathrm{~cm}$ abatement for concretes of the groups I and II, respectively. The molding of the specimens for the axial compression tests and the determination of the static modulus of elasticity followed the requirements of ABNT [24] standard, using cylindrical metal molds with $10 \mathrm{~cm}$ diameter. For the pullout test, $20 \mathrm{~cm}$-shaped cubic wood molds were made, as recommended by CEB [25] (Figure 1). The steel bars were cleaned and prepared so that the lamination marks did not remain in the adherent part and the protection for the non-adherent part was made with PVC pipes. The thickening process in the cylindrical specimens was made with a manual 2-layer socket with 12 strokes each. For the cubic specimens, mechanical compaction with a needle-type vibrator was used.

At the end of concreting, the specimens were covered with plastic sheeting to prevent evaporation of the water present in the mixture and, after 24 hours, they were demolded and relocated. The curing was performed by daily rinsing the specimens for 15 days. After that, they were stored in a place without sun and wind. This procedure was performed for all cylindrical and cubic samples, with the same curing factors (setting).

\section{Table 1}

Concrete admixtures

\begin{tabular}{ccccc}
\hline Concrete & Cement: Sand: Gravel Ratio & a/w relationship & Additive & Group \\
\hline \multirow{2}{*}{ C30 } & $1: 2.5: 3.5$ & 0.51 & $0 \%$ & Group I \\
& $(110.8: 277.1: 387.9) \mathrm{kg}$ & $60.4 \mathrm{~kg}$ & 0.32 & cement \\
C65 & $1: 1.34: 2.16$ & $56.4 \mathrm{~kg}$ & $0.882 \mathrm{~kg}$ & Group II \\
\hline
\end{tabular}


(a)

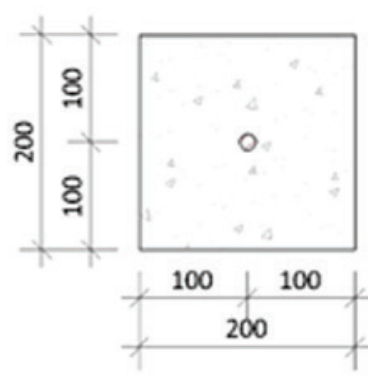

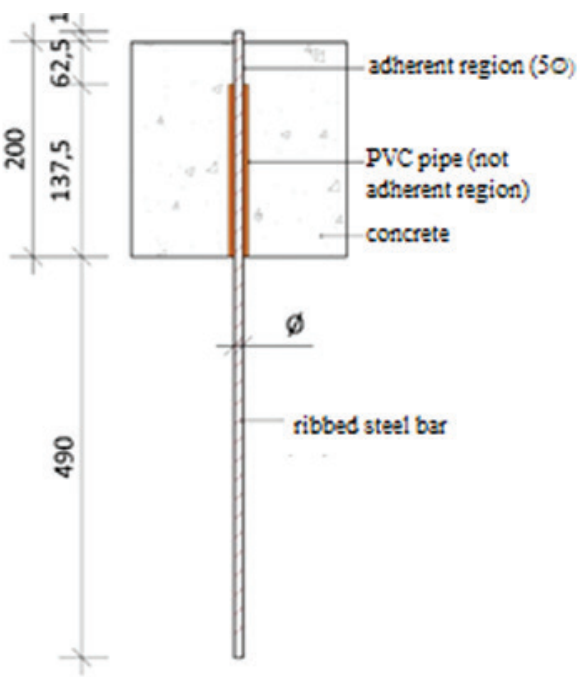

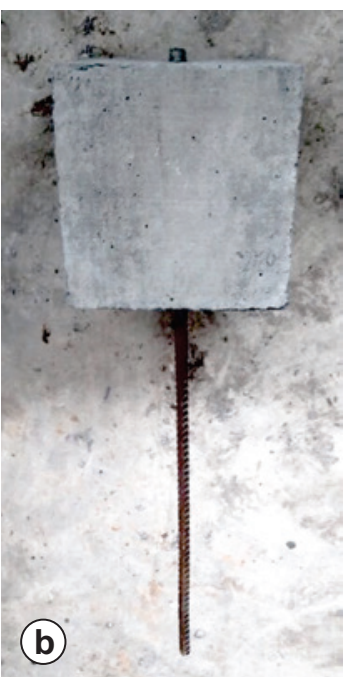

\section{Figure 1}

Test specimen for the pullout test (a) layout: dimensions in $\mathrm{mm}(\mathrm{b})$ photo

The experimental program is shown in Figure 2. Three samples were molded for each setting condition to determine the axial compression and elastic modulus and five samples were molded for each pullout test, resulting in 60 cylindrical and 45 cubic samples. Samples of each concrete class (group) were exposed to rising temperature: 23 (room temperature, reference for the work), 400 and $800{ }^{\circ} \mathrm{C}$. The 28 days of age was used as a standard, considered the reference for resistance design. 90 days of age was used because the stabilization of the concrete internal reactions takes place at this time, according Metha and Monteiro [26]. After this time, the chemical reactions that occur in the concrete tend to stabilize, consequently reducing the interference that could be caused by the effects of chemical reactions.

The samples for the pullout test have part of the reinforcement exposed that required special protection in order to avoid direct exposure to high temperatures, because in concrete structures the rein- forcement is always encased. During the exposure of group II at 28 days glass wool was used for protection. However, the glass wool was not adequate at high temperature because it was transformed into glass at temperatures above $400{ }^{\circ} \mathrm{C}$. Nevertheless, these samples were submitted to the resistance tests because probably there was no influence of heating on the exposed parts of the bars, since all heating process was monitored by K-type thermocouples, showing similar curves in all exposures. Therefore, the change in protective materials did not interfered in the results. In addition, the results of this work were similar to others, as Scotton [8]. For all other exposures, rock wool was used which showed better insulation.

The heat treatment was carried out in an electric oven (Novus $\mathrm{N} 1200$, Brazil). The heating rate was $3^{\circ} \mathrm{C} / \mathrm{min}$ according to RILEM [27] and each maximum temperature was held for 30 minutes.

The procedures of ABNT standard [28] were used for the compressive strength tests. The test was performed in a $200 \mathrm{kN}$

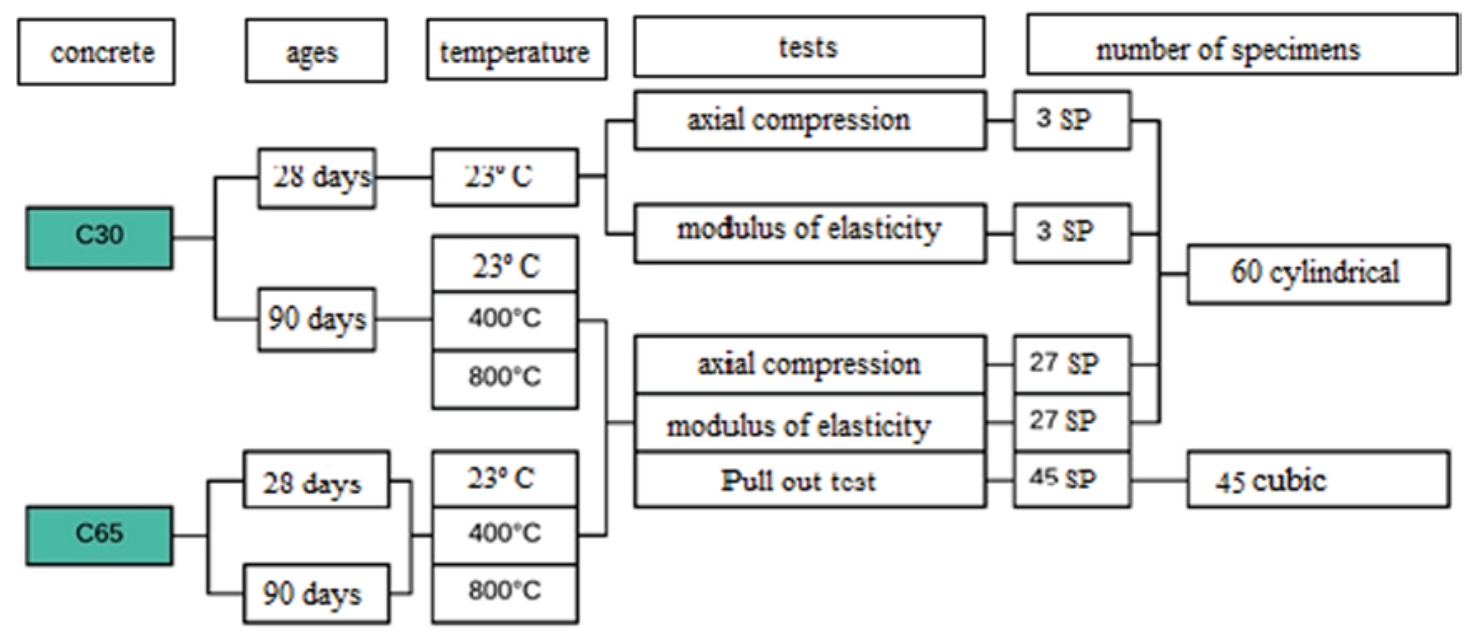

Figure 2

Organizational chart with the experimental matrix 


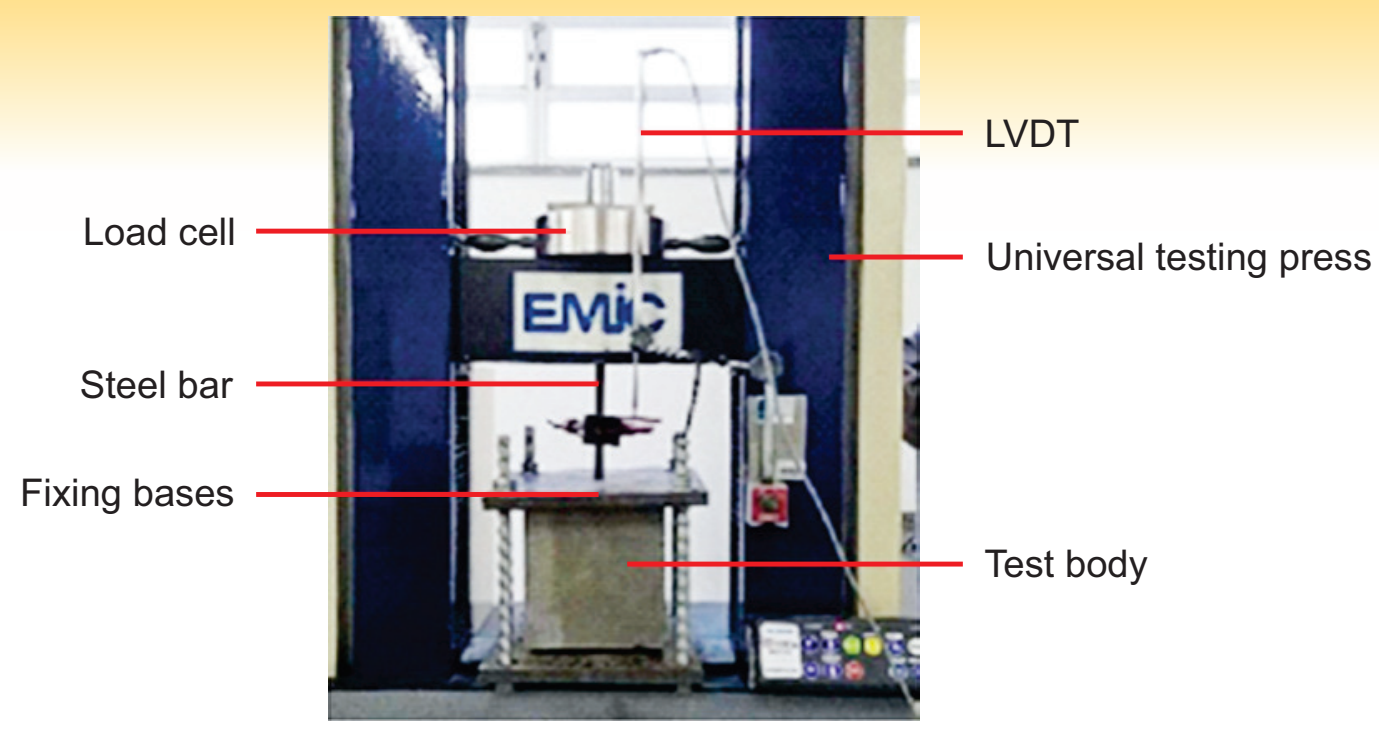

\section{Figure 3}

Pullout test

hydraulic press (EMIC PC200I, Brazil) using the TESC (Test Script) software. The samples were placed in the press and capped with neoprene. The determination of the static elastic modulus by the compression test was performed on a $200 \mathrm{kN}$ servo hydraulic press (EMIC PC200CS) according the ABNT standard [29]. In this test, strain gauges were used following the methodology A: fixed stress. The pullout test followed was performed according the CEB recommendations [25] in a 30 ton universal testing machine (EMIC DL30000, Brazil). The steel bar was pulled out along the longest end by a tensile force, the other remaining without tension. The specimens were placed in the support with the longest bar length facing upwards (Figure 3). A linear variable differential transformer (LVDT) device measured the relative displacement between steel and concrete and the load was determined by a $250 \mathrm{kN}$ load cell connected to a computer by the Catman Easy software. The tensile load, which was loaded in the same direction as the reinforcement, but in the opposite direction, was increased until the rupture of the sample. The loading speed

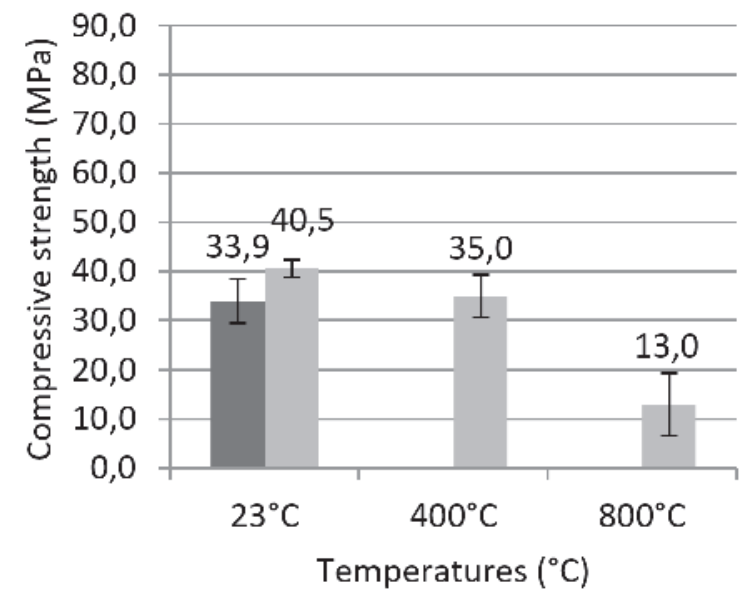

$\square 28$ days $\quad 90$ days

(a) was $10 \mathrm{~mm} / \mathrm{min}$, not in accordance with CEB [25] that states $78.125 \mathrm{~N} / \mathrm{s}$. In this study it was not possible to control the speed by the applied load, only by displacement, due to equipment limitations. Therefore, curves of load versus sliding of the steel bar were obtained.

The bond stress $\left(\tau_{\mathrm{b}}\right)$ is calculated according to Equation 01 , dividing the tensile load by the bond area. There are different ways of calculating the grip. Leonhardt and Mönnig [16] have used Equation 01, however, assigning the tensile load at the displacement of $0.01 \mathrm{~mm}$. In this work the calculation was based on the works of Scotton [8] and Silva [30] that used the ultimate stress at break. According to Silva [30], the bonding stress is considered evenly distributed, not corresponding to the actual condition.

$\tau_{\mathrm{b}}=\frac{\mathrm{P}}{\pi \emptyset l_{\mathrm{o}}}$

Where: $\tau_{b}$ : ultimate bonding stress; $P$ : ultimate tensile load; $\varnothing$ : diameter of steel bar; $\mathrm{I}_{\mathrm{o}}$ : length of bonding.

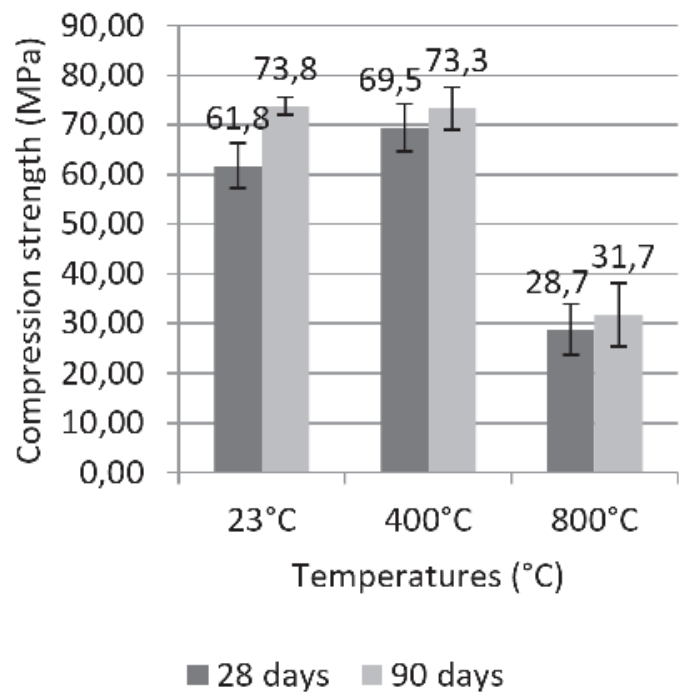

(b)

Figure 4

Compressive strength: (a) group l; (b) group II 
Table 2a

Tukey's test for compressive strength

\begin{tabular}{|c|c|c|c|c|c|}
\hline \multirow{2}{*}{ Group and age } & \multirow{2}{*}{$\begin{array}{l}\text { Temperature } \\
\left({ }^{\circ} \mathrm{C}\right)\end{array}$} & \multirow{2}{*}{$\begin{array}{c}\text { Average strength } \\
\text { (MPa) }\end{array}$} & \multicolumn{3}{|c|}{ p-value } \\
\hline & & & $23^{\circ} \mathrm{C}$ & $400{ }^{\circ} \mathrm{C}$ & $800^{\circ} \mathrm{C}$ \\
\hline \multirow{3}{*}{$\begin{array}{l}\text { Group I } \\
\text { (90 days) }\end{array}$} & $23^{\circ} \mathrm{C}$ & 40.54 & - & 0.3308 & 0.000797 \\
\hline & $400^{\circ} \mathrm{C}$ & 34.96 & 2.208 & - & 0.002271 \\
\hline & $800^{\circ} \mathrm{C}$ & 12.97 & 10.87 & 8.662 & - \\
\hline \multirow{3}{*}{$\begin{array}{l}\text { Group II } \\
\text { (28 days) }\end{array}$} & $23^{\circ} \mathrm{C}$ & 61.77 & - & 0.2048 & 0.0005682 \\
\hline & $400^{\circ} \mathrm{C}$ & 69.47 & 2.762 & - & 0.0003195 \\
\hline & $800^{\circ} \mathrm{C}$ & 28.73 & 11.85 & 14.61 & - \\
\hline \multirow{3}{*}{$\begin{array}{l}\text { Group II } \\
\text { (90 days) }\end{array}$} & $23^{\circ} \mathrm{C}$ & 73.8 & - & 0.9901 & 0.0002633 \\
\hline & $400^{\circ} \mathrm{C}$ & 73.28 & 0.1907 & - & 0.000267 \\
\hline & $800^{\circ} \mathrm{C}$ & 31.67 & 16.08 & 15.89 & - \\
\hline
\end{tabular}

\section{Results and discussions}

The results were statistically analyzed using the ANOVA (Variance Analysis) technique to verify if there was a significant difference between the studied variables, using the Statistica 7 software, available at UNESC. When this difference was relevant, the Tukey test was used to assess which groups were different from each other. Both tests were performed considering $95 \%$ reliability.

\subsection{Compressive strength of concrete samples}

The axial compressive strength for concretes of groups I and II after exposure to high temperature at 28 and 90 days of age is shown in Figure 4.

According to the ANOVA analysis, for the compressive strength at
90 days for both groups of concrete exposed at room temperature, 400 and $800^{\circ} \mathrm{C}$, the coefficient of determination was 0.878 , that is, $87.8 \%$ of the total variation is explained by the change in compressive strength. At $5 \%$ significance $(\alpha=0.05)$ there are differences in the compressive strength at 90 days for both groups and for different temperatures. By Tukey's method, Table 2(a), not all exposure temperatures had an influence on compressive strength. Comparing the compressive strength at 23 and at $400{ }^{\circ} \mathrm{C}$ the results are statistically equivalent. However, there are differences when comparing the strength at $800^{\circ} \mathrm{C}$ with 23 and $400{ }^{\circ} \mathrm{C}$.

At 90 days, in both groups, the compressive strengths decreased when the specimens were submitted to high temperatures, the largest reductions for group I, 13.6 and $68 \%$, respectively, for 400 and $800{ }^{\circ} \mathrm{C}$. Ergün et al [9] achieved reductions of 19 and $73 \%$ at the same temperatures.
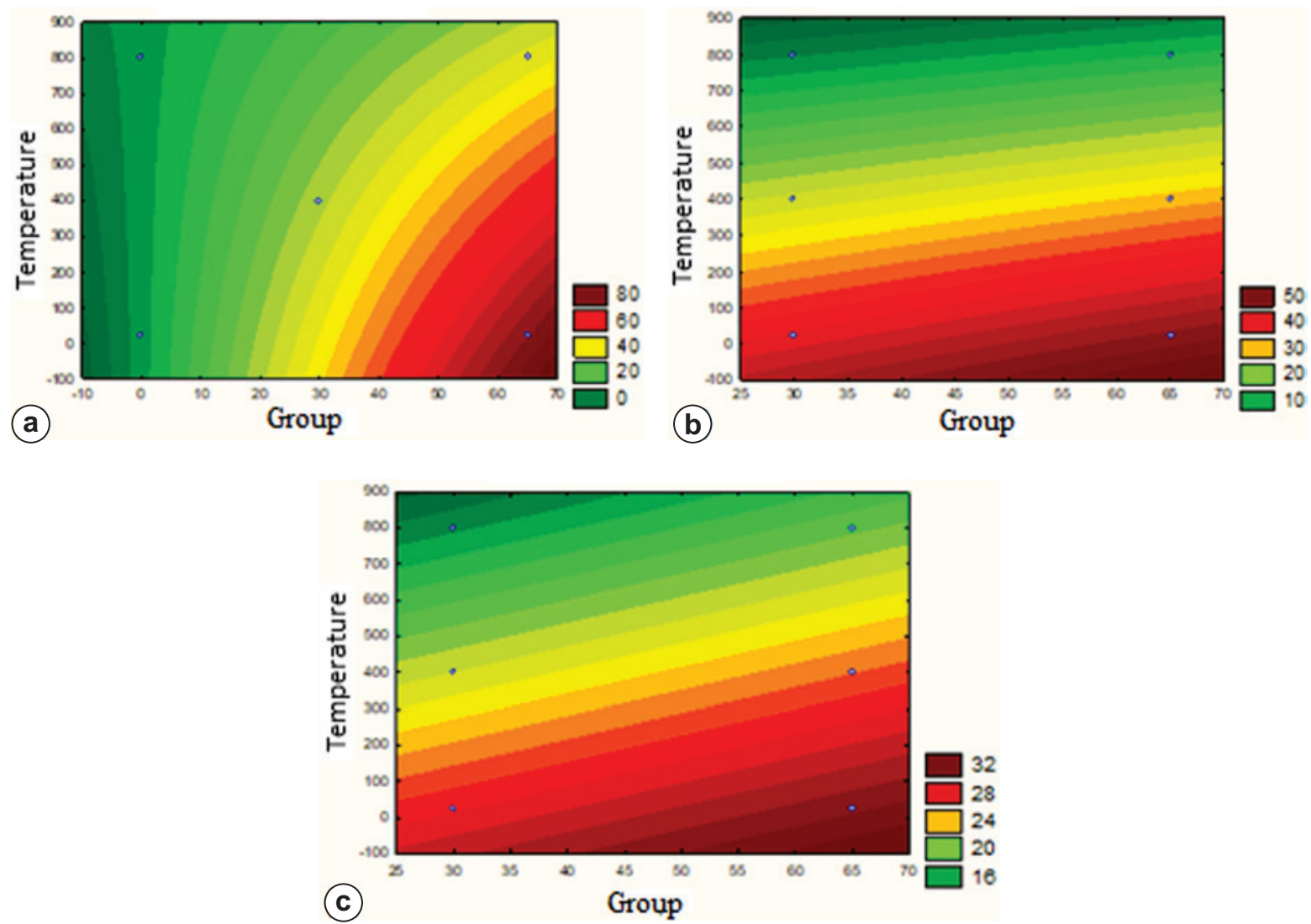

\section{Figure 5}

Response surface for groups I and II at 90 days for 23,400 e $800^{\circ} \mathrm{C}$ : (a) compressive strength; (b) modulus of elasticity; (c) bond strength 


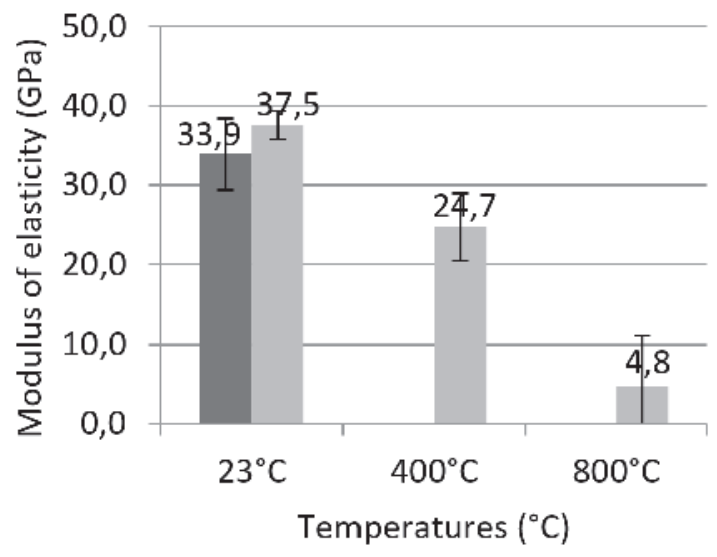

$\square 28$ days $\quad 90$ days

(a)

\section{Figure 6}

Modulus of elasticity: (a) group l; (b) group II

At the age of 28 days for group II there was a $12.5 \%$ increase in strength at $400{ }^{\circ} \mathrm{C}$ and a reduction of $53.6 \%$ at $800{ }^{\circ} \mathrm{C}$. Scotton [8] found no change in strength at $400^{\circ} \mathrm{C}$ in comparison to room temperature. At $600^{\circ} \mathrm{C}$, the highest temperature studied by Scotton [8], there was a of reduction $29 \%$.

The response surface for the compressive strength at 90 days is shown in Figure 5(a) considering the groups and temperature. There is little variation in group II (Class 65) when exposed to temperatures of 23 and $400{ }^{\circ} \mathrm{C}$. The highest compressive strengths are obtained for group II at room temperature, with estimated values of $74 \mathrm{MPa}$.

\subsection{Static modulus of elasticity to compression}

The average and standard deviation of the modulus of elasticity for concretes of groups I and II is shown in Figure 6 in function of temperature and age. At 28 days, it was not possible to perform the test for group II at $800{ }^{\circ} \mathrm{C}$ because the specimens suffered

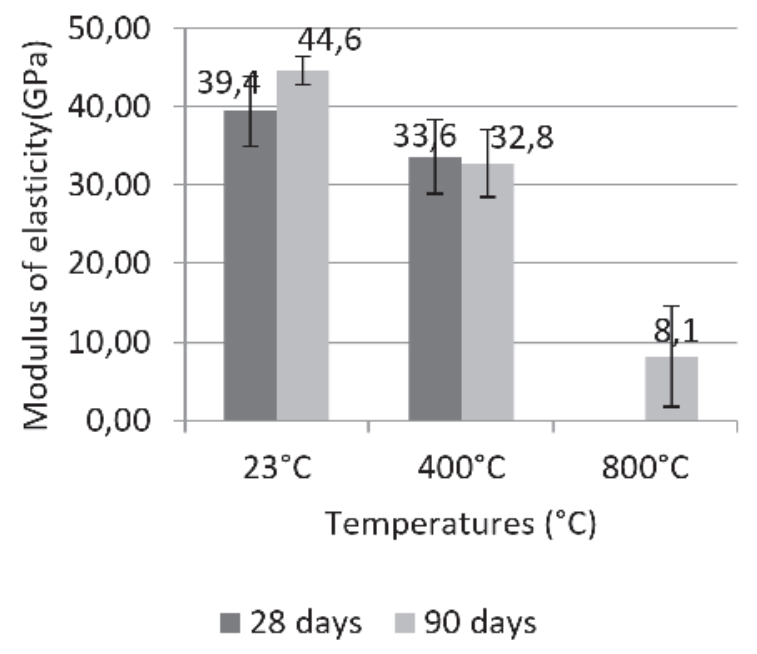

(b)

cracks and splinters, that is, spalling. For both groups, the modulus increases with increasing age because the cement reactions are stabilized and the effect of temperature is higher than age in the compressive strength. The modulus of elasticity decreased when the specimens were submitted to 400 and $800{ }^{\circ} \mathrm{C}$. At 90 days the reductions in strength were, respectively, 26.5 and 81.8 $\%$ for group I and 34.1 and $87.2 \%$ for group II. Morales et al [31] achieved a reduction in elastic modulus of approximately $46 \%$ at $300^{\circ} \mathrm{C}$ and $73 \%$ at $450^{\circ} \mathrm{C}$.

For the ANOVA, for both groups, at 90 days, at room temperature, 400 and $800^{\circ} \mathrm{C}$, the coefficient of determination was 0.977 , i.e., $97.7 \%$ of the total variation is explained by the variation of the modulus of elasticity. The variation in temperature significantly affected the modulus of elasticity, Table 2(b) and Figure 5(b). The factor 'groups' and the interaction between 'groups' versus 'temperature' were not statistically significant for this property. The largest modulus of elasticity takes place for group II at room temperature, 45 GPa estimated, Figure 5(b).

\section{Table $2 b$}

Tukey's test for the pullout test

\begin{tabular}{|c|c|c|c|c|c|}
\hline \multirow{2}{*}{ Group and age } & \multirow{2}{*}{$\begin{array}{c}\text { Temperature } \\
\left({ }^{\circ} \mathrm{C}\right)\end{array}$} & \multirow{2}{*}{$\begin{array}{c}\text { Average strength } \\
\text { (MPa) }\end{array}$} & \multicolumn{3}{|c|}{$\mathrm{p}$-value } \\
\hline & & & $23^{\circ} \mathrm{C}$ & $400^{\circ} \mathrm{C}$ & $800^{\circ} \mathrm{C}$ \\
\hline \multirow{3}{*}{$\begin{array}{l}\text { Group I } \\
\text { (90 days) }\end{array}$} & $23^{\circ} \mathrm{C}$ & 23.926 & - & 0.4005 & 0.0007719 \\
\hline & $400^{\circ} \mathrm{C}$ & 27.098 & 1.898 & - & 0.0002555 \\
\hline & $800^{\circ} \mathrm{C}$ & 11.67 & 7.325 & 9.222 & - \\
\hline \multirow{3}{*}{$\begin{array}{l}\text { Group II } \\
\text { (28 days) }\end{array}$} & $23^{\circ} \mathrm{C}$ & 30.01 & - & 0.5334 & 0.0002217 \\
\hline & $400^{\circ} \mathrm{C}$ & 31.55 & 1.553 & - & 0.0001937 \\
\hline & $800^{\circ} \mathrm{C}$ & 20.1 & 9.98 & 11.53 & - \\
\hline \multirow{3}{*}{$\begin{array}{l}\text { Group II } \\
\text { (90 days) }\end{array}$} & $23^{\circ} \mathrm{C}$ & 29.11 & - & 0.9239 & 0.006774 \\
\hline & $400^{\circ} \mathrm{C}$ & 27.95 & 0.538 & - & 0.01324 \\
\hline & $800^{\circ} \mathrm{C}$ & 17.45 & 5.371 & 4.833 & - \\
\hline
\end{tabular}




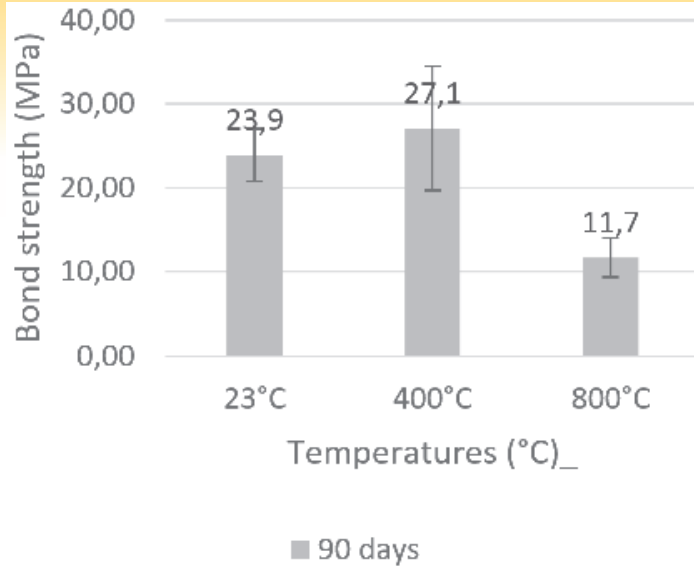

(a)

\section{Figure 7}

Bond strength: (a) group l; (b) group II

\subsection{Steel-concrete bond stress}

The results of bond stress by the pullout test for groups I and II after exposure to temperatures is shown in Figure 7. In the Analysis of Variance of the bond stress at 90 days of age for both groups at room temperature, 400 and $800{ }^{\circ} \mathrm{C}$, the coefficient of determination was 0.71 , that is, $71 \%$ of the total variation is explained by the variation of bond stress. There was no significant difference at 95 $\%$ confidence for temperature.

By the Tukey test, the strengths were statistically similar at $400{ }^{\circ} \mathrm{C}$, but significant differences occurred at $800{ }^{\circ} \mathrm{C}$ for both groups, Table 2 (b). For group I, at $400{ }^{\circ} \mathrm{C}$, there was a resistance increase of $13.4 \%$ and at $800{ }^{\circ} \mathrm{C}$ a reduction of $51.1 \%$. At $400{ }^{\circ} \mathrm{C}$, for group II at 28 days, there was an increase in bond resistance of $5.33 \%$. At $800{ }^{\circ} \mathrm{C}$, reductions of 33 and $39.9 \%$ were observed at the ages of 28 and 90 days, respectively. In Scotton's work [8], a 2 $\%$ increase was observed at $400^{\circ} \mathrm{C}$ and at $600^{\circ} \mathrm{C}$ there was a 29 $\%$ reduction in the first concreting at 28 days. In $80 \mathrm{MPa}$ compressive strength concretes, Caetano [6] obtained at $470{ }^{\circ} \mathrm{C}$ a $50 \%$ reduction in bond strength. Ergün et al [9] found reductions of 21, 27, 60 and $76 \%$ at $200,400,600$ and $800^{\circ} \mathrm{C}$, respectively, at 90 days. There are significant differences at $800{ }^{\circ} \mathrm{C}$ for bond stress, Figure 5(c), response surface. The highest bond stress at 90 days are

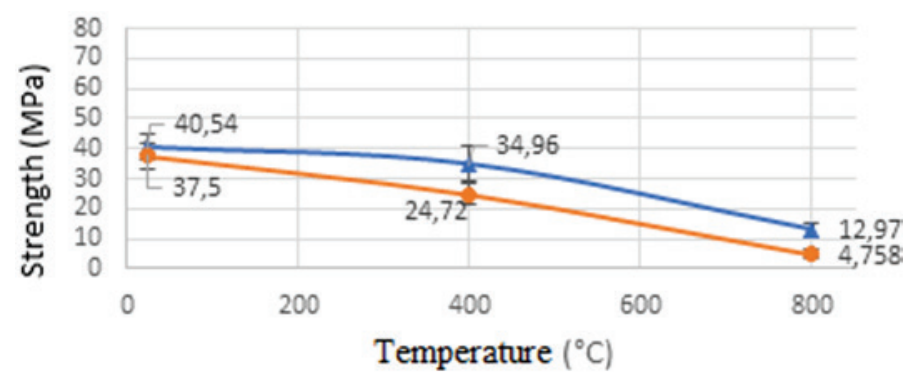

- Compression strength $\rightarrow$ Bond strength

(a)

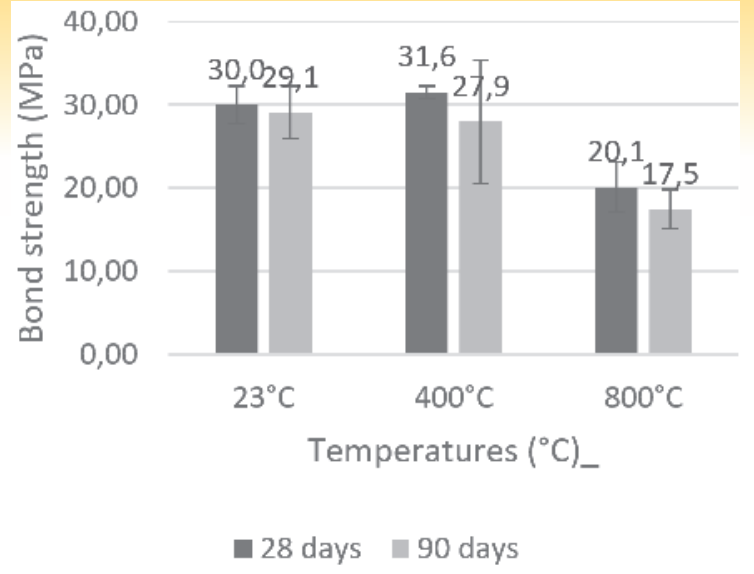

(b)

obtained once again for the combination of group II at room temperature, with estimated values of $30 \mathrm{GPa}$.

By the Tukey test, for 28 days (Table 2(b)), not all temperatures had an influence on compressive strength. Comparing the bond stresses at 23 and $400{ }^{\circ} \mathrm{C}$, they are statistically similar. Comparing the results at 800 with 23 and $400{ }^{\circ} \mathrm{C}$, there are significant differences, similar at 90 days.

The fact that significant changes start after $400{ }^{\circ} \mathrm{C}$ may be due to the dehydration process of the $\mathrm{C}-\mathrm{S}-\mathrm{H}$ gel that starts at $100^{\circ} \mathrm{C}$ and ends near $400{ }^{\circ} \mathrm{C}$. Lima [15] states that during this process water release occurs and, in some cases, formation of anhydrous silicates and calcium oxide $(\mathrm{CaO})$. During cooling, partial rehydration of these components may occur. For samples heated above $600{ }^{\circ} \mathrm{C}$ and then cooled, the $\mathrm{CaO}$ rehydrates, causing expansion that may contribute to the appearance of cracks in the concrete, making it fragile.

\subsection{Comparative analysis between compressive strength and bond stress}

Comparing the curves of compressive strength and bond stress for group I, Figure 8(a), they show a similar behavior. Group II, Figure 8(b), shows similar behavior between the different ages, but with significant statistical difference for compressive strength between ages.

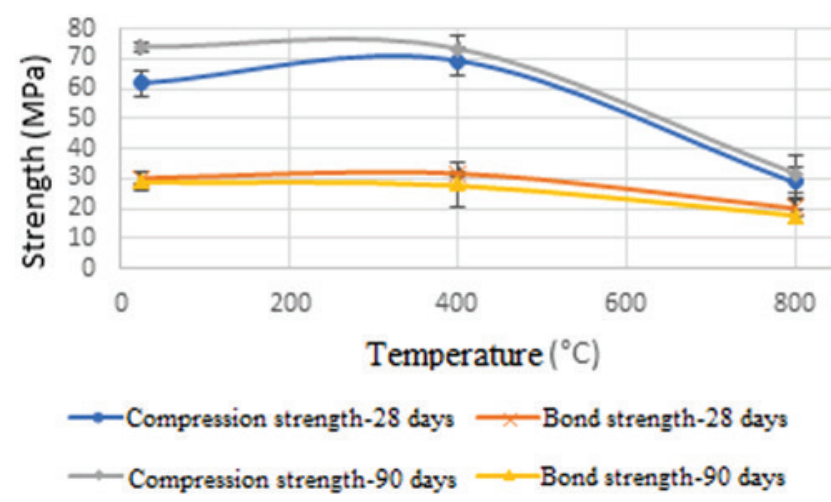

(b)

\section{Figure 8}

Comparative analysis between compressive strength and bond strength: (a) group I at 90 days; (b) group II at 28 and at 90 days 


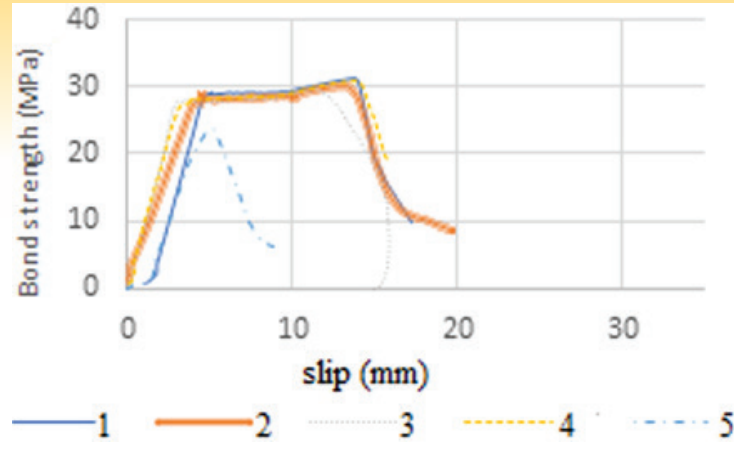

(a)

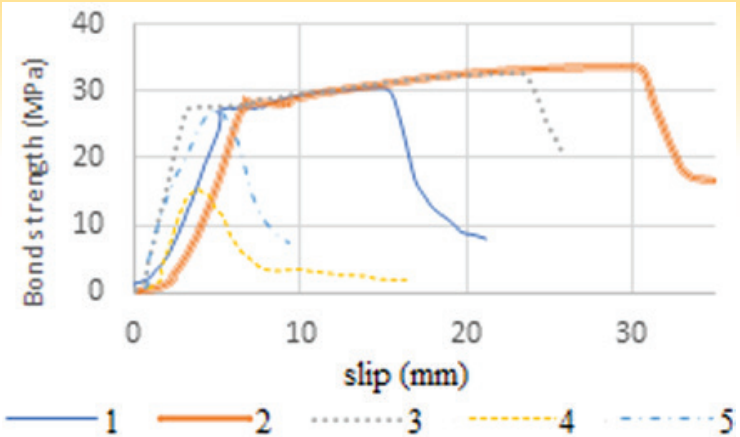

(b)

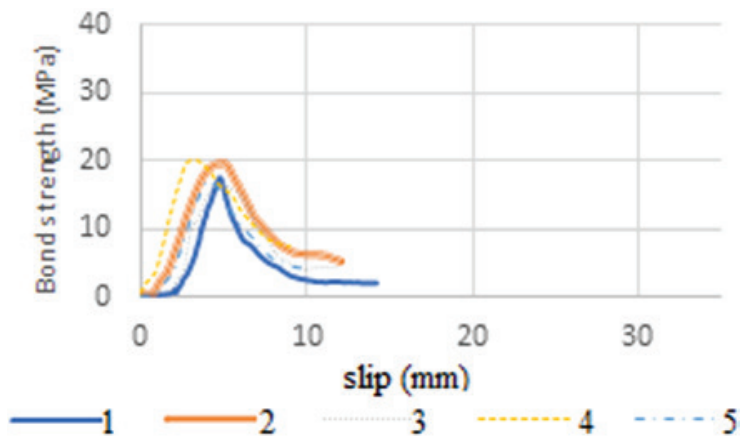

(c)

\section{Figure 9}

Bond strength-slip curve, group II at 90 days: (a) $23^{\circ} \mathrm{C}$, (b) $400^{\circ} \mathrm{C}$, (c) $800^{\circ} \mathrm{C}$

\subsection{Bond stress-slip correlation}

The curve of bond stress versus slippage for the concrete of group Il at 90 days, after exposure at 23,400 and $800{ }^{\circ} \mathrm{C}$ is shown in Figure 9 . At $23^{\circ} \mathrm{C}$, only the specimen SP5 was cracked, for the others, there was sliding and flow of the steel bar. At $400{ }^{\circ} \mathrm{C}, \mathrm{SP} 4$ and SP5 samples were cracked and sliding occurred in the others; at $800{ }^{\circ} \mathrm{C}$ all specimens were cracked.

\subsection{Bond stress characteristic versus effective strength}

The ABNT Brazilian standard [1] establishes an equation to determine the design stress. As in this work the bending test was not performed, ABNT [1] admits the correlation between the average tensile strength and the characteristic compressive strength (fck). Therefore, for group I with fck $=30 \mathrm{MPa}$, the design bond stress is $3.26 \mathrm{MPa}$. For group II with fck $=65 \mathrm{MPa}$ the design stress is 5 $\mathrm{MPa}$. In all groups, even after exposure to high temperature, the bond continues to meet the required value for project design, emphasizing that the Brazilian standard is in favor of safety.

\section{Conclusions}

The results of this work show that the performance of both compressive strength and bond stress, for concretes of both groups, changes when subjected to different (and rising) temperature.

The bonding and compressive strength curves were similar at room temperature. At $400{ }^{\circ} \mathrm{C}$ there was no significant variation for them and at $800{ }^{\circ} \mathrm{C}$ there was significant loss of strength in all cases. Therefore, there is a close relationship between bond stress and compressive strength. As Caetano [6] quotes, exposure to high temperatures considerably affects bond strength after $400{ }^{\circ} \mathrm{C}$. At the age of 90 days, for the $30 \mathrm{MPa}$ and $65 \mathrm{MPa}$ concretes, the reduction in bond strength at $800{ }^{\circ} \mathrm{C}$ was 51.1 and $39.9 \%$, respectively, which shows the significant loss of bond, compromising the structure.

This work and others, as Scotton's [8], show that up to $400{ }^{\circ} \mathrm{C}$ a small increase in strength can occur. In this study, there was a 12.5 $\%$ increase in compressive strength and $5.33 \%$ in bond strength for group II at 28 days. High temperatures significantly reduced the modulus of elasticity, with reductions higher than $80 \%$ at $800{ }^{\circ} \mathrm{C}$. The age had no significant influence on the bond stress of concrete in both groups. For a better analysis of the bond stress versus slip curve, good reinforcement confinement is important so that splitting failure does not occur before the bar slips.

\section{References}

[1] ASSOCIAÇÃO BRASILEIRA DE NORMAS TÉCNICAS. Projeto de estruturas de concreto - procedimento - NBR 6118, Rio de Janeiro, 2014.

[2] TAVARES, A. J. et al. Aderência aço-concreto: simulação numérica dos ensaios de arranchamento pull-out e APULOT usando o programa ATENA. Rev. IBRACON Estrut. Mater., São Paulo, v. 7, n. 1, Feb. 2014; p. 138-157, 2014. [3] ARAÚJO, J. M. de. Curso de Concreto Armado, Rio Grande: Dunas, 4ed, 4 v. (Volume 1), 2014.

[4] CASTRO, C.M. Concreto de Alto Desempenho: Estudo da Aderência com a Armadura sob Ações Repetidas, São Carlos, 2002, Dissertação (Mestrado em Engenharia de Estruturas) - Escola de Engenharia de São Carlos, Universidade de São Paulo. 
NEGRÃO, D.E. e PIMENTEL, L.L. Aderência compósito $x$ aço: influência do diâmetro da barra de aço. In: XVII Encontro de Iniciação Científica e II Encontro de Iniciação em Desenvolvimento Tecnológico e Inovação, São Paulo, Set 2012, Anais.

[6] CAETANO, L. F. Estudo do comportamento da aderência em elementos de concreto armado submetidos à corrosão e elevadas temperaturas, Porto Alegre, 2008, Dissertação (Mestrado em Engenharia) - Programa de Pósgraduação em Engenharia Civil, Universidade Federal do Rio Grande do Sul, 153 f.

[7] OLIVEIRA, L. C. B e JACINTHO, A. E. P. G. A. Estudo da influência do diâmetro da barra na aderência entre o aço e o concreto convencional. In: XVII Encontro de Iniciação Científica e II Encontro de Iniciação em Desenvolvimento Tecnológico e Inovação, São Paulo, Set 2012, Anais.

[8] SCOTTON, J. A. Comportamento da aderência Armadura-Concreto em situações não usuais: Efeito de altas temperaturas, Porto Alegre, 2013. $96 \mathrm{f}$. Trabalho de Conclusão de Curso (Graduação) - Escola de Engenharia, Departamento de Engenharia Civil, Universidade Federal do Rio Grande do Sul, 96 f.

[9] ERGÜN, A.; KÜRKLÜ, G.; BASPINAR, M. S. The effects of material properties on bond strength between reinforcing bar and concrete exposed to high temperature. Construction and Building Materials 112-Elsevier, 2016, p. 691-698.

[10] MORELY, P.; ROYLES, R. Response of the bond in reinforcing concrete to high temperatures Mag. Concr. Res., 35 (123), 1983, p. 67-74 Google Scholar apud

[11] HADDAD, R.; SHANNIS, L. Post-fire behavior of bond between high strength pozzolanic concrete and reinforcing steel. Construction and Building Materials, 18-Elsevier, 2004, p. 425-435 apud

[12] HADDAD, R.; AL-SALEH, R.J.; AL-AKHRAS, N.M. Effect of elevated temperature on bond between steel reinforcement and fiber reinforced concrete Fire Saf. J., 43, 2008, p. 334-343 apud

[13] BINGOL, A.F.; GUL, R. Residual bond strength between steel bars and concrete after elevated temperatures. Fire Saf. J., 44, 2009, p. 854-859 apud

[14] SILVA, D. dos S. da. Propriedades mecânicas residuais após incêndio de concretos usados na construção civil na grande Florianópolis, Florianópolis, 2009. Dissertação (Mestrado) - Curso de Engenharia Civil, Programa de Pós-graduação em Engenharia Civil, Universidade Federal de Santa Catarina, $102 f$

[15] LIMA, R. C. A. Investigação do comportamento de concretos em temperaturas elevadas, Porto Alegre, 2005. Tese (Doutorado) - Curso de Escola de Engenharia, Programa de Pós-graduação em Engenharia Civil, Universidade Federal do Rio Grande do Sul, $257 \mathrm{f}$.

[16] LEONHARDT, F.; MÖNNIG, E. Construções de concreto: Princípios básicos do dimensionamento de estruturas de concreto armado, Rio de Janeiro: Interciência, v. 1, $1^{\text {a }} \mathrm{Ed}, 1977$.

[17] FLETCHER, I.; BORG, A.; HITCHEN, N.; WELCH, S.Performance of concrete in fire: A review of the state of the art, with a case study of the windsor tower fire. BRE Research Publications, Edinburgh Research Archive, Edinburgh, GB, 2006.

[18] POLOJU, K. K.; MANCHIRYAL, R. K.; RAHUL. C. Strength Studies on Different Grades of Concrete Considering Fire Exposure. American Journal of Civil Engineering. Vol. 6, No. 1, 2018, pp. 16-23. doi: 10.11648/j. ajce.20180601.14

[19] EL-FITIANY, S.; YOUSSEF, M. Interaction Diagrams for Fire-Exposed Reinforced Concrete Sections, Canadá, Engineering Estructures, v. 70, 2014, p. 246-259.

[20] KHOURY, G. A. Effect of Fire on Concrete and Concrete Structures. Progress in Structural Engineering and Materials, v. 2, n. 4, 2000, p. 429-447.

[21] ASSOCIAÇÃO BRASILEIRA DE NORMAS TÉCNICAS. Concreto para fins estruturais - NBR 8953, Rio de Janeiro, 2015.

[22] ASSOCIAÇÃO BRASILEIRA DE NORMAS TÉCNICAS. Agregados - Determinação da composição granulométrica- NBR NM 248, Rio de Janeiro, 2003.

[23] ASSOCIAÇÃO BRASILEIRA DE NORMAS TÉCNICAS. Concreto - determinação da consistência pelo abatimento do tronco de cone - NBR NM 67, Rio de Janeiro, 1998.

[24] ASSOCIAÇÃO BRASILEIRA DE NORMAS TÉCNICAS. Concreto - Procedimento para moldagem e cura de corpos de prova - NBR 5738, Rio de Janeiro, 2015.

[25] COMITE EURO-INTERNACIONAL DU BÉTON. RILEM/ CEB/FIP RC6: Bond test for reinforcing steel: 2-Pull-out test, Suíça, 1983, P. [1-5].

[26] METHA, P. Kumar, MONTEIRO, Paulo J. M. "Concreto - estrutura, propriedades e materiais”. Ed. PINI. São Paulo, 2018.

[27] RILEM TC 129 MHT: Test Methods for Mechanical properties of concrete al high temperatures, Shrinkage, 2000, part 9.

[28] ASSOCIAÇÃO BRASILEIRA DE NORMAS TÉCNICAS. Concreto - Ensaio de compressão de corpos-de-prova cilíndricos - NBR 5739, Rio de Janeiro, 2017.

[29] ASSOCIAÇÃO BRASILEIRA DE NORMAS TÉCNICAS. Concreto - Determinação do módulo estático de elasticidade à compressão - NBR 8522, Rio de Janeiro, 2008.

[30] SILVA, B.V. Proposição de um teste de aderência para o controle tecnológico da resistência à compressão do concreto, Porto Alegre, 2014. Tese (Doutorado em Engenharia Civil) - Programa de Pós-Graduação em Engenharia Civil, Universidade Federal do Rio Grande do Sul.

[31] MORAles, G.; CAMPOS. A.; FAgARELLO, A. M. P. Ação do fogo sobre os componentes do concreto. In: Semina: Ciências Exatas e Tecnológicas, v. 32, n. 1, p. 4755, Londrina, 2011. 